SLAVERY AND THE ECONOMY OF SÃO PAULO

$$
\text { I } 750-\text { I } 850
$$




\section{SOCIAL SCIENCE HISTORY}

\section{Edited by Stephen Haber and David Brady}

David Brady and Mathew D. McCubbins, Party, Process, and Political Change in Congress

Jeffrey Bortz and Stephen Haber, The Mexican Economy, 1870-1930

Edward Beatty, Institutions and Investment

Jeremy Baskes, Indians, Merchants, and Markets

William Summerhill, Order Against Progress

Noel Maurer, The Power and the Money 


\section{SLAVERY AND THE ECONOMY OF SÃO PAULO I $750-$ I 850}

FRANCISCO VIDAL LUNA AND

HERBERT S. KLEIN

STANFORD UNIVERSITY PRESS

Stanford, California

2003 
Stanford University Press

Stanford, California

(C) 2003 by the Board of Trustees of the

Leland Stanford Junior University. All rights reserved.

Library of Congress Cataloging-in-Publication Data

Luna, Francisco Vidal.

Slavery and the Economy of São Paulo, 1750-1850 / Francisco Vidal Luna and Herbert S. Klein.

p. cm.-(Social science history)

Includes bibliographical references and index.

ISBN 0-8047-4465-3 (cloth : alk. paper)

1. São Paulo (Brazil : State)-Economic conditions.

2. Sugar trade-Brazil-São Paulo (State)-History.

3. Coffee industry-Brazil-São Paulo (state)-

History. 4. Slavery-Brazil-São Paulo (State)-

History. 5. Slaves - Brazil-São Paulo (State)-History.

I. Klein, Herbert S. II. Title. III. Series.

HC188 .S386 2002

$330.981^{\prime} 61033-\mathrm{dc} 21 \quad 2002010785$

Original Printing 2003

Last figure below indicates year of this printing:

$\begin{array}{llllllllll}12 & 11 & 10 & 09 & 08 & 07 & 06 & 05 & 04 & 03\end{array}$

Typeset by GES Typesetters in 10.5/13 Bembo 
To Matiko and Crystal Lane Klein 
